\title{
Journalism as a Collaboration between Citizen and Journalist Media
}

\author{
Dudi Iskandar \\ \{dudi.iskandar@gmail.com \}
}

Lecturer at Faculty of Communication Science of Budi Luhur University, South Jakarta, Indonesia

\begin{abstract}
Interactive is the keyword of the development of communication technology today. Through a network that is always online everyone can be involved in a production on the web. This also applies to the world of journalism. Interactive is the core of the changing order of contemporary journalism. With interactive mode, journalism is not a product of media institutions but also individuals. The professionalism of media journalists and individual skills is a collaboration of upcoming journalism trends. Journalism is not only just the work of professional journalists as was defined before the internet era, but also, not in the form of individual products in terms of citizen journalism. Through a qualitative approach, an analysis of the development of journ alism, and a literature study, this research concludes several things. First, journalism trends must lead to collaborative institutions and individuals who are concerned with the world of journalism so that they can complement and correct the available data. Second, journalism is always online and must be at least like a wiki site that can be complementary. Third, journalism collaboration with social media only occurs if it meets the requirements such as online media, collaboration, and interactive.
\end{abstract}

Keywords: interactive, journalism, collaboration

\section{Introduction}

The presence of the internet in the development of mass communication has changed the development of mas s media, es pecially journalis $\mathrm{m}$. The internet is also what later popularized the term new media. ${ }^{1}$ The internet trig gered two fundamental changes in the journalis m environment, journalistic process and the form of media organizations.

Changing in the pattern of journalismhas caused journalis $m$ to experience a crisis marked by five indicators. Namely, the collapse of circulation, the fall in advertising revenue, the diffusion of attention, the crisis of authority, and finally the inability or unwillingness of journalism to question the structure of power. ${ }^{2}$ While changes in the forms of media org anizations present media convergence. Although convergence is an ambiguity concept. ${ }^{3}$

Therefor the world of journalis mis undergoing a very radical change. The internet has triggered journalism in two ways, speed, and space. Also, multiplicity, interaction, and participation. ${ }^{4}$ Freedom of opinion, interaction, and creation through the internet creates a phenomenon of freedom that has never happened in previous eras. So the news must be redefined from the proposition of serving the public to respect the individual in the use and satisfaction of the media and medium. ${ }^{5}$

Before the internet era journalis $m$ was the product of an institution called mass media. The presence of the internet in the early days then gave rise to the terminology of citizen journalism. Now along with the times, journalism is not only a product of media institutions or individuals but a shared product between media institutions and individuals. The key to the process of journalis mlike this is interactive. In this concept, the news is produced and produced jointly by

\footnotetext{
${ }^{1}$ Baran, Stanley J. Baran. 2008. Pengantar Komunikasi Massa: Budaya dan Melek Media. Translator S. Rouli Manalu. Jakarta. Erlangga.

${ }^{2}$ Siapera, Eugenia. 2012. Understanding New Media. California. USA : Sage Publications. pp 127

3 Storsul, Tanja and Dagny Stuedahl (ed). 2007. Ambivalence Toward Convergence; Digitalization and Media Change. Goteborg. Sweden. Nordicom. pp 13

${ }^{4}$ Allen, Stuart (Ed). 2010. The Routledge Companion to News and Journalism. London. Routledge pp 557

${ }^{5}$ Mersey, Rachel Davis. 2010. Can Journalism Be Saved ; Rediscovering America's Appetite for News. Santa Barbara. California. Preager. pp 93
} 
media institutions and individuals. The two complement each other. This is what journalis m calls collaboration.

\section{Media Convergence}

Henry Jenkins ${ }^{6}$ defines convergence as a process of continuous unification that occurs between various parts of the media such as technology, industry, content and audiences. And, that happens continuously. Whereas Burnett and Marshall ${ }^{7}$ define convergence as a merging of the media, telecommunications and computer industries into a unified form and function as a communication medium in digital form. In line with the two definitions above, Bob Franklin et. $\mathrm{al}^{8}{ }^{8}$ emphasized that media convergence is an exchange among all media with different characteristics and platforms.

Thus media convergence can be understood as an integration or unification of some conventional media with the advancement of information technology into one roof or a company. Convergence is not only the unification of content - a news story can appear in various media that are in one company, but also the unification in one media holding company. Media convergenceallows a group of companies in addition to having conventional media, including social media.

Convergence is also the application of digital technology, namely the integration of text, sound, numbers and images. Dailey, Demo, and Spillman ${ }^{9}$ explained media convergence activities including cross-promotion, cloning, coopetition (collaboration), content sharing, and full convergence. With media convergence, the news that used to becalled preaching events that have already happened, now the definition is changed to events that are happening..

Media convergence turns out not only to influence changes in the journalis tic process, but also to various aspects of life. It will have an impact on public media consumption, public perception, information dissemination, and media literacy. Media convergence presents a new social media construction that is unprecedented. ${ }^{10}$

\section{Citizen Journalism}

With the internet, now any one can become a reporter. The profession so far belongs to those who seek news for the benefit of media institutions. The individuals who produce this popular journalism are called citizen journalism. Historically, citizen journalism was an idea invented by Jay Rosen. ${ }^{11}$ They discussed the concept of journalism for the public that could convey is sues that were important to the public. J.D. Lasica, ${ }^{12}$ explained citizen journalism into five types. First, independent news or information websites, pure participatory news sites, collaborative media sites, other forms of thin media, and personal broadcasting sites.

According to Burn ${ }^{13}$ citizen reports have three advantages compared to traditional mass media news. Namely, citizen reports are those that have reported about the incident. He was immediately present at the crime scene. On the other hand, for the media or journalists many events are missed so the news value is biased because it is not fromthe first hand. The farther from the news source the more biased the news. Many interests and hands in the event, especially if in contact with the interests of the public at large.

Second, the citizens' writings about an event that were published became an alternative reading for the community fromthe readings presented by traditional media. The community has

\footnotetext{
6 Jenkins, Henry. 2006. Convergence Culture; Where Old and New Media Collide. USA : New York University Press.

${ }^{7}$ Burnett, R. and Marshall, P.D. 2003 Web Theory : An Introduction, London : Routledge. pp 1

${ }^{8}$ Franklin, Bob, et.al. 2005. Key Concepts in Journalisme Studies, New Delhi, Sage Publications India Pvt. Ltd. pp 49-50

${ }^{9}$ Haryanto, Ignatius. 2014. Jurnalisme Era Digital; Tantangan Industri Media Abad 21. Jakarta : Kompas Media Nusantara. pp 212

${ }^{10}$ Sugihartati, Rahma. 2014. Perkembangan Masyarakat Informasi dan Teori Sosial Kontemporer. Jakarta : Kencana Prenadamedia Group.pp 89.

${ }^{11}$ the Pew Research Center and the Poynter Institute

12 Haryanto, Ignatius. 2014. Jurnalisme Era Digital; Tantangan Industri Media Abad 21. Jakarta : Kompas Media Nusantara. pp 212.

${ }^{13}$ Burn, Axel. 2009. Gatewatching: Collaboration Online News Production. New York. Peter Lang
} 
so far only received news or reading material from one source. With the emergence of citizen journalis $\mathrm{m}$, society has alternations and comparisons in various as pects. Third, citizen journalis $m$ can be accessed 24 hours a day and seven days a week. This is certainly different from traditional media which is very limited in terms of presentation and delivery of information.

Therefore, the more citizen journalis mthe better the development of information obtained by the public. Information is increasingly diverse. There are more versions of the truth. Verification of facts is increasingly plural. For democracy and maturity this condition is very good.

Steve Outing,${ }^{14}$ who is very concerned with citizen journalism, stated in The 11 Layers of Citizen Journalis $m$. That the steps in citizen journalism are opening up to public comment, the citizen add-on reporter, the citizen bloghouse, now we're getting serious : open-source reporting, news room citizen transparency blogs, the stand-alone citizen-journalism site: edited version (stand-alone citizen journalis $\mathrm{m}$ ), the stand-alone citizen journalis $\mathrm{m}$ site: unedited version (standalone citizen journalism), and add a print edition.

\section{Research Me thods}

This researchuses a qualitative approach. That is, the type of research conducted will produce findings that are not obtained by statistical procedures or other quantification approaches. The s pecialcharacteris tic of qualitative research is that it seeks to express the uniqueness of certain individuals, groups, communities and/or organizations in their daily lives (Bas rowi \& Sukidin, 2015). Moleong (2010) while quoting David Williams (1995) summarizes understanding, definition, and scope according to scientists who are concerned with qualitative research. Qualitative research is the collection of data in a natural setting, using natural methods, and carried out by people or researchers who are naturally interested.

This paper begins by describing the development of information and communication technology and the reality of contemporary journalis m. After that, it shows various theories that underlie the need for a new model of study in journalism. Then presents an offer in examining the reality of contemporary journalism. Finally, discussing journalism as a collaboration.

The approach used in this study is qualitative. Data collection is through library research and analy sis of library data (documents) and critically analyzing the phenomenon and reality of contemporary journalism. Library research (document analys is) is one way to extract data from books, journals, and or sites according to the themes discussed in this paper.

To show the results of research on the need model journalism in the world of contemporary journalis $m$, the author explores the reality of journalism as a whole. Then map journalism from the perspective of the new model of journalism. That is journalism as a collaboration.

\section{Result and Discussion}

Journalism keeps changing. Journalism is always challenged by the development of newer communication technologies. So he was required to adjust. The World Association of News papers states there are six trends in the effect of the internet on journalism. First, the explosion of participative journalism or community-generated content. Second, the rise of audience research by media companies to learn new patterns of media us age. Third, proliferation of personalized news delivered online and on mobile devices. Fourth, reorganization of news rooms optimised for audience focus. Fifth, the development of new forms of storytelling geared toward new audiences and channels. Sixth, the growth of audience-focused news judgment and multimedia news judgment. ${ }^{15}$

\footnotetext{
${ }^{14}$ www.poynter.org

${ }^{15}$ Obijiofor, Levi and Folker Hanusch. 2011. Journalism Across Culture; An Introduction. London. Palgrrave MacMilan pp 179.
} 
John V. Pavlik ${ }^{16}$ added in the digital world, journalis mexperienced five areas of change. (1) Newsgathering and reporting. (2) Information storage, indexing, and retrieval, especially multimedia content. (3) The processing, production, and editorial.(4) Distribution and publishing. (5) Appearance, layout, and access.

In contemporary reality, there is no longer anything, including theindependence of media organizations. Media editors cannot be separated from the various interests that influence and encompass it. Editorial decisions in a news story in journalistic reality today are not without involving the voice of the founder, owner, or shareholder or audience/audience. In the voice of the founder, owner, or shareholder is not included in the editorial ranks, but journalism now, especially business-economic and political-power news, cannot possibly ignore their letters. Thus in the reality of journalismtoday there is a shift from independent to interdependence. If media organizations join the public, then we call it journalism as a collaboration.

This shift is not a bad thing, but it is a necessity from the socio-cultural changes that coverorare outside the realmof journalis mat the macro level. It seems to be independent of the interviewee and the absence of a conflict of interest in the understanding of Jack Fuller ${ }^{17}$ is only a myth and an impossibility if we look at the reality of today's media. The internet triggers the presence of online journalismor news sites clearly and decisively changes the various habits and mechanisms in traditional journalis m such as print media.

Throughout the search of Roger Fidfler ${ }^{18}$ and Henry Jenkins ${ }^{19}$ media convergence began with the idea of Ithiel de Sola Pool in 1983 in his work Technology Freedom. In his work, Jenkins said that he continued the program that had been pioneered by the MIT Media Laboratory which described media convergence as below.

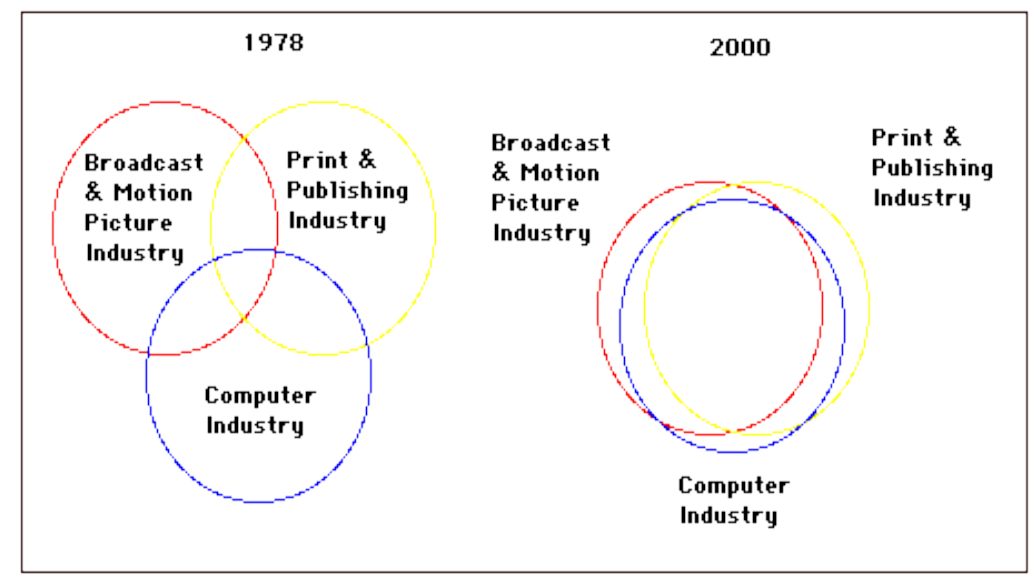

With these diagrams Negroponte made the case for the creation of a Media Laboratory at MIT.

Figure 1.

Comparative of Negroponte and MIT Media Laboratory in Media Convergence

According to Rich Gordon ${ }^{20}$ convergence is divided into five dimensions. First, owners hip convergence. Second, tactical convergence. Third, structural convergence. Fourth, information gathering convergence. Fifth, storytelling convergence. In the context of this paper

\footnotetext{
${ }^{16}$ Pavlik, John V. 2001. Journalism and New Media. New York. Columbia University Press. pp 194

${ }^{17}$ Fuller, Jack. 2010. What is Happening to News. Chicago. Chicago Press

${ }^{18}$ Fidler, Roger. 2003. Mediamorfosis. Translator Hartono Hadikusumo. Yogyakarta. Bentang Pustaka

19 Jenkins, Henry. 2006. Convergence Culture; Where Old and New Media Collide. USA : New York University Press.

${ }^{20}$ Gordon, Rich. 2003. The Meaning and Implications af Convergence. Rowman \& Littlfield Inc Oxford.
} 
what happens is the convergence of the fourth point (convergence of news gathering) and the fifth (convergence of news packaging). ${ }^{21}$

Convergence news gathering exists when journalists have diverse skills. He can write, take pictures, operate the camera, and so on. This is what is called multi-tasking and multi-skill reporters. In this convergence, journalis ts require to share the results of their coverage into various forms of media. Print coverage can be made for television and news sites. While in news convergence(storytelling convergence) mustbe reporters to be able to read the public as readers, audiences, or viewers. With this model, news as a journalistic work is complemented by various forms. The example writing has graphics, photos, and videos.

AugustE. Grant ${ }^{22}$ adds about journalistic convergence. That journalistic convergence necessitates a change in the mindset of the media about news and its coverage not only to the extent of delivering different news to different media such as print media, broadcasting, and sites. There are three models in journalistic convergence: the convergence of newsrooms, newsgathering and news content.

In subsequent developments, media convergence not only joins the threeparts (computer, broadcasting, and print as reflected in Figure I), but widens the ongoing process in which content, technology, audiences, and industries intertwine with one another, including social media as illustrated below.

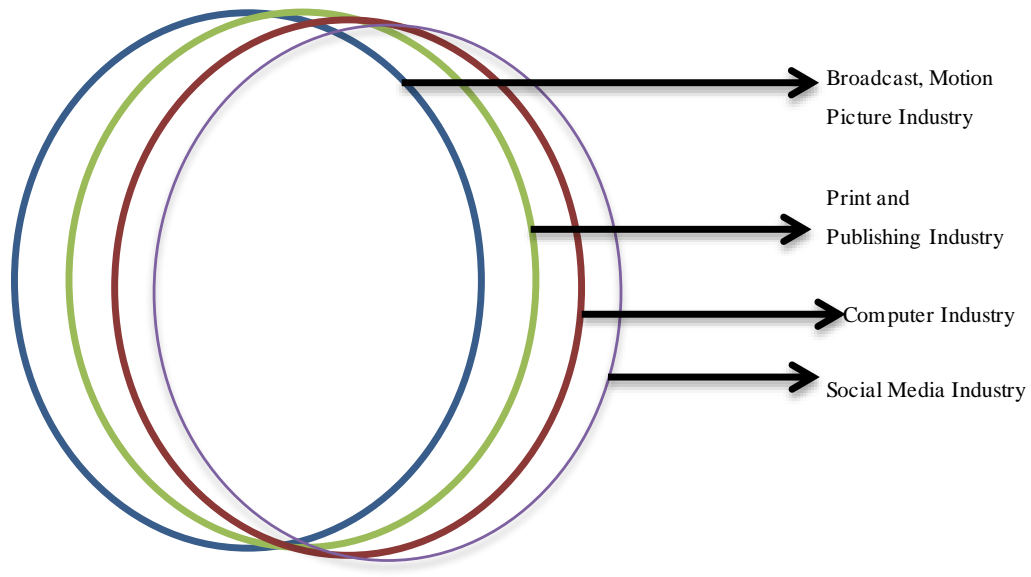

Figure 2.

The form of developing media convergence with social media in the field of Negroponte Media Convergence and the MIT Media Laboratory

The convergence of journalis $m$ through social media above, then there are several keywords, requirements, and conditions of this model of journalis $m$. First, there is a news site that is always online 24 hours 7 days managed by an agency/media institution. Second, there is citizen participation as a form of citizen journalism. Third, the collaboration will happen between journalist media and active citizens who read the news. Fourth, both media and citizen journalism must be actively involved so that they are interactive in the events reported. The key to journalis $m$ as collaboration lies in its interactivity.

$\mathrm{Jim} \mathrm{Hall}^{23}$ defines interactive as an addition in which users can participate and modify in form and content in one condition all the time. Thus there is a change from journalism without social media with journalism the result of collaboration with social media. This also has

\footnotetext{
${ }^{21}$ Quinn, Stephen and Vincent F. Filak. 2004. Convergent Journalism; An Introduction. Oxford. Focal PressElsevier. pp 4-6

${ }^{22}$ Grant, August E. 2009. Understanding Media Convergence. Oxford University Press pp 33

23 Hall, Jim. 1992. Online Journalism; A Critical Primer. London. Pluto Press. pp 49
} 
cons equences for changes in the pillars of journalism. At least three journalismprinciples change, objective to authenticity, verification to transparency, and independence to collaboration. ${ }^{24}$

The form of collaboration is like Wikipedia. ${ }^{25}$ Anyone can upload events on a collaboration website. Anyone can edit news that has been uploaded on a collaboration website. The essence of this collaboration is interactive. From an event uploaded on a collaboration website, anyone can participate. Journalism is increas ingly diverse. It is no longer one-way, linear journalis $\mathrm{m}$. There is no longer journalis $\mathrm{m}$ that is controlled by one stakeholder. There is no capitalist journalism anymore; owner of power; the owner of a certain ideology. Journalis m belongs to all citizens. This is the core of journalis m as a collaboration.

\section{Conclusions}

Based on observations, searches, and literature studies on contemporary journalism, severalconclu sions can be drawn. First, journalismtrends must lead to collaborative institutions and individuals who are concerned with the world of journalis ms o that they can complement and correct the available data. Second, journalism is always online and must be at least like the Wikipedia site which can be a complementary arena. Third, journalis m collaboration with social media only occurs if it meets the requirements such as online media, collaboration, and interactive.

\section{References}

[1] Baran, Stanley J. Baran.. Pengantar Komunikasi Massa: Budaya dan Melek Media. Translator S. Rouli Manalu. Jakarta. Erlangga. (2008)

[2] Siapera, Eugenia. Understanding New Media. California. USA : Sage Publications. pp 127. (2012)

[3] Storsul, Tanja and Dagny Stuedahl (ed). Ambivalence Toward Convergence; Digitalization and Media Change. Goteborg. Sweden. Nordicom. pp 13. (2007)

[4] Allen, Stuart (Ed). The Routledge Companion to News and Journalism. London. Routledge pp 557. (2010)

[5] Mersey, Rachel Davis. Can Journalism Be Saved ; Rediscovering America's Appetite for News. Santa Barbara. California. Preager. pp 93. (2010)

[6] Jenkins, Henry. Convergence Culture; Where Old and New Media Collide. USA : New York University Press. (2006)

[7] Burnett, R. and Marshall, P.D. Web Theory : An Introduction, London : Routledge. pp 1. (2003).

[8] Franklin, Bob, et.al. Key Concepts in Journalisme Studies, New Delhi, Sage Publications India Pvt. Ltd. pp 49-50. (2005).

[9] Haryanto, Ignatius. Jurnalisme Era Digital; Tantangan Industri Media Abad 21. Jakarta : Kompas Media Nusantara. pp 212. (2014)

[10] Sugihartati, Rahma. Perkembangan Masyarakat Informasi dan Teori Sosial Kontemporer. Jakarta : Kencana Prenadamedia Group.pp 89. (2014)

[11] the Pew Research Center and the Poynter Institute

[12] Haryanto, Ignatius. Jurnalisme Era Digital; Tantangan Industri Media Abad 21. Jakarta : Kompas Media Nusantara. pp 212. (2014)

[13] Burn, Axel.. Gatewatching: Collaboration Online News Production. New York. Peter Lang. (2009) [14] www.poynter.org

[15] Obijiofor, Levi and Folker Hanusch. Journalism Across Culture; An Introduction. London. Palgrrave MacMilan pp 179. (2011)

[16] Pavlik, John V. Journalism and New Media. New York. Columbia University Press. pp 194 . (2001)

[17] Fuller, Jack. What is Happening to News. Chicago. Chicago Press. (2010)

[18] Fidler, Roger. Mediamorfosis. Translator Hartono Hadikusumo. Yogyakarta. Bentang Pustaka. (2003)

[19] Jenkins, Henry. Convergence Culture; Where Old and New Media Collide. USA : New York University Press. (2006)

[20] Gordon, Rich. The Meaning and Implications af Convergence. Rowman \& Littlfield Inc Oxford. (2003)

\footnotetext{
24 Bossio, Diana. 2017. Journalism and Social Media. Practitionery, Organizations, and Institutions. Switzerland. Palgrave McMilan. pp 28-40

${ }^{25}$ Siapera, Eugenia. 2012. Understanding New Media. California. USA : Sage Publications. pp 131
} 
[21] Quinn, Stephen and Vincent F. Filak. Convergent Journalism; An Introduction. Oxford. Focal Press-Elsevier. pp 4-6. (2004)

[22] Grant, August E. Understanding Media Convergence. Oxford University Press pp 33 . (2009)

[23] Hall, Jim. Online Journalism; A Critical Primer. London. Pluto Press. pp 49. (1992)

[24] Bossio, Diana. Journalism and Social Media. Practitionery, Organizations, and Institutions. Switzerland. Palgrave McMilan. pp 28-40. (2017)

[25] Siapera, Eugenia. Understanding New Media. California. USA : Sage Publications. pp 131. (2012) 